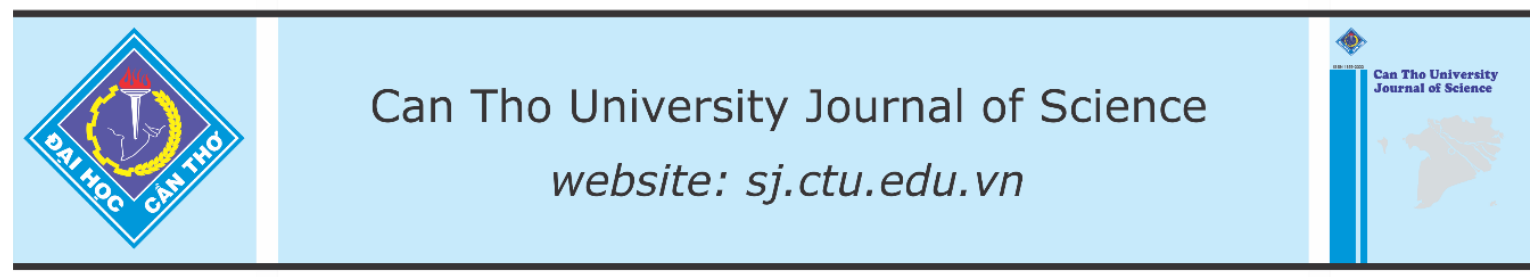

DOI: 10.22144/ctu.jen.2021.033

\title{
Evaluation of the purification process of phosvitin extracted from chicken egg yolk using liquid chromatography
}

Vo Van Song Toan ${ }^{1 *}$, Le Thi Bao Tran ${ }^{3}$, Tran Khoa Nguyen ${ }^{1}$, Huynh Thanh Nam ${ }^{1}$,

Nhan Hoang Thinh ${ }^{1}$ and Tao Viet $\mathrm{Ha}^{2}$

${ }^{1}$ Biotechnology Research and Development Institute, Can Tho University, Viet Nam

${ }^{2}$ Tay Do University, Viet Nam

${ }^{3}$ Master student of Department of Life Sciences, National Central University, Taiwan

*Correspondence: Vo Van Song Toan (email:vvstoan@ctu.edu.vn)

\section{Article info.}

Received 04 Mar 2021

Revised 13 May 2021

Accepted 19 Jul 2021

\section{Keywords}

Chromatography, egg yolk, phosvitin, purification, temperature

\section{ABSTRACT}

Phosvitin from chicken egg yolk, known as a phosphoglycoprotein, owns a very strong metal chelating property due to its polyanionic character. This study aimed to evaluate the factors affecting the purification process and suitable conditions to increase phosvitin's purity. Phosvitin was separated from yolk granules by using $10 \%$ of $\mathrm{NaCl}$ solution in $0.05 \mathrm{M}$ $\mathrm{NaOH}$ solution and heat treatment which removes lipoprotein from the extracted solution. The highest phosphorus content $(58.14 \mathrm{mg}$ ) and phosphorus recovery rate $(32.4 \%)$ were obtained at thermal treatment of $30^{\circ} \mathrm{C}$ for 30 minutes. In addition, phosvitin was purified using anion-exchange chromatography (AEC) and gel-filtration chromatography (GFC). The fraction $1\left(F_{1}\right)$ obtained from AEC using UNO-Sphere $Q$ at $p H 8$ had the recovery rate of phosvitin approximately $72.73 \%$. Furthermore, fraction $F_{1}$ was separated on GFC to obtain two main sub-fractions $\left(F_{1}\right.$ and $\left.F_{2}\right)$. Sub-fraction $F_{1}$ from gel filtration was composed mostly of $\beta$-phosvitin with a high recovery rate $(81.93 \%)$ while $F_{2}$ was dominant with $\alpha$ phosvitin in a lower phosvitin recovery rate (16.89\%). These findings will provide useful information for further researches on other properties of phosvitin so that it can be applied widely in human needs.

\section{INTRODUCTION}

Eggs of avian species have been considered as a valuable source of nutrients for humans. In recent years, the egg's structural and functional characteristics have been researched, which increased an understanding not only of the nutritional contribution of eggs but also their bioactive properties.

Overall, eggs are composed of three main parts, including $63 \%$ egg whites, $27.5 \%$ egg yolk, and 9.5\% eggshell with the eggshell membrane (Bertrand, 2012). On top of that, egg yolk is uti- lized more commonly in food products as it combines various nutritional and functional properties (Anton et al., 2007). Egg yolk has a complex structure with two main fractions (granules and plasma). Plasma accounts for $78 \%$ of yolk dry matter and consists of $85 \%$ low-density lipoproteins (LDL) and $15 \%$ livetin (Burley \& Cook, 1961). Granules represent about $22 \%$ of yolk solids on a dry weight basis corresponding to $70 \%$ high-density lipoproteins (HDL), 16\% phosvitin, and 12\% LDL (Burley \& Cook, 1961). HDL-phosvitin complex is a basic unit of granule linked by phosphocalcic 
bridges between the phosphate groups of their phosphoserine residues (Causeret et al., 1991).

Phosvitin is a major protein in the egg yolk with a large number of phosphate groups in its structure (Mecham \& Olcott, 1949). More than 50\% of amino acids in the polypeptide chain of phosvitin are serine and most of them are phosphorylated. Therefore, phosvitin has a strong metal chelating capacity, which makes it a potential candidate for natural antioxidant and antibacterial agents (Khan et al., 2000; Ishikawa et al., 2004).

Over the last 60 years, various separation and purification methods for phosvitin from the egg yolk had been developed using a 3-step process, including lipid removal using ethanol, hexane, methanol; extraction of phosvitin from lipid-free fraction using $\mathrm{NaCl}$; and finally, precipitation of the extracted phosvitin using $\mathrm{NaCl},\left(\mathrm{NH}_{4}\right)_{2} \mathrm{SO}_{4}$. For further purification, AEC and GFC were used (Castellani et al., 2003; Lei \& Wu, 2012; Zhang et al., 2011).

Most of the separation processes of phosvitin reported in the previous studies were used organic solvents like chloroform, hexane, methanol, and ethanol to remove lipid and phospholipid from the yolk granules. Therefore, the extracted phosvitin has limited use, especially for human demand. Also, these methods are relatively complicated, and the solvents cause denaturation and modification of phosvitin structure and reduce the recovery rate (Ko et al., 2011). Several methods for phosvitin purification have been introduced to improve the purity of phosvitin. Therefore, the objective of this study is to build the optimal procedure to increase the purity of phosvitin and get a high yield of phosvitin.

\section{MATERIALS AND METHODS}

\subsection{Materials}

Chicken eggs less than 7 days old were purchased from the Coopmart supermarket, Can Tho city, Viet Nam. UNO-Sphere Q and Sephadex G-75 resins were bought from Bio-Rad Laboratory (USA) and Pharmacia Fine Chemicals (Sweden), respectively. Bovine Serum Albumin and Coomassie Brilliant Blue G-250 (CBB) were obtained from Merck (Germany). Other reagents were of analytical grade from local sources.

\subsection{Preparation of phosvitin}

Phosvitin was extracted from the egg yolk according to the method described by Lee et al. (2014) with some modifications. The egg yolk was sepa- rated from egg white, homogenized with two volumes of distilled water, and centrifuged at 7,000 rpm for 15 minutes. The precipitant containing yolk granule was collected, homogenized with four volumes of $10 \% \mathrm{NaCl}$ solution $(\mathrm{wt} / \mathrm{w})$ in $0.05 \mathrm{M}$ $\mathrm{NaOH}$ solution using a cell disruptor (Microson, USA). The homogenate was diluted with an equal volume of distilled water and centrifuged at the same speed and time to extract phosvitin. The supernatant was collected and desalted using dialysis.

\subsection{Investigation of the effects of temperature on the phosvitin extraction process}

The desalted phosvitin was heat-treated in a water bath at $30,70,80,90$, and $100^{\circ} \mathrm{C}$ for 30 minutes. After heating, the sample solution was kept for 30 minutes at room temperature before centrifugation at $10,000 \mathrm{rpm}$ for 10 minutes. The supernatant was collected and used to determine the total protein content using Bradford's method (1976) and the phosphorus content.

Phosphorus content was determined using colorimetric measurement of phosphorus as molybdenum blue after dry-ashing (Pulliainen \& Wallin, 1994). Phosvitin contains $10 \%$ phosphorus and accounts for $80 \%$ phosphorus in the egg yolk (Mecham \& Oclott, 1949), so the phosvitin content was calculated by multiplying the phosphorus content by 8 . The phosphorus recovery was obtained based on the assumption that $17 \mathrm{mg}$ of egg yolk contains $66.2 \mathrm{mg}$ of phosphorus.

\subsection{Anion-exchange chromatography}

The best treatment from the preceding experiment was chosen for this experiment. $20 \mathrm{~mL}(62.53 \mathrm{mg})$ of the phosvitin extract obtained from the best treatment was loaded to a UNO-Sphere Q column equilibrated with $0.02 \mathrm{M}$ Tris- $\mathrm{HCl}$ buffer $\mathrm{pH} 8$ in advance. The chromatographic elution was run by a Biorad system (USA) at the flow rate of 1 $\mathrm{mL} / \mathrm{min}$ with buffer $\mathrm{A}$ as $0.02 \mathrm{M}$ Tris- $\mathrm{HCl} \mathrm{pH} 8$ and buffer $\mathrm{B}$ as $1 \mathrm{M} \mathrm{NaCl}$ in buffer $\mathrm{A}$. The effluent was monitored at $280 \mathrm{~nm}$.

\subsection{Gel-filtration chromatography}

$30 \mathrm{~mL}(33 \mathrm{mg})$ of protein obtained from the $F_{1}$ fraction of anion-exchange chromatography was loaded into the Sephadex G-75 column $(2 \times 60$ $\mathrm{cm})$. The column was equilibrated in advance with $0.1 \mathrm{M}$ ammonium acetate buffer $\mathrm{pH}$ 5. The elution was carried out with the same buffer at the flow rate of $0.75 \mathrm{~mL} / \mathrm{min}$. The effluent was collected in $5 \mathrm{~mL}$ fractions and was monitored at $280 \mathrm{~nm}$. 


\subsection{Sodium dodecyl sulfate-polyacrylamide gel electrophoresis (SDS-PAGE)}

SDS-PAGE technique was performed using $1 \mathrm{~mm}$ thickness gel with $10 \%$ separating gel containing $30 \%$ acrylamide solution, Tris- $\mathrm{HCl} 1.5 \mathrm{M}(\mathrm{pH} 8.8)$, $10 \%$ SDS solution, $10 \%$ ammonium persulfate, and Tetramethylethylenediamine (TEMED). The extracted phosvitin obtained from each experiment was mixed with sample buffer and heated at $100^{\circ} \mathrm{C}$ in a water bath for $10 \mathrm{~min}$. Standard proteins (14.4 $-116 \mathrm{kDa}$ ) were used as molecular markers.

Electrophoresis was performed with Bio-Rad system (Bio-Rad Laboratory, Inc. USA) by applying $20 \mathrm{~mA}$ in current at the first 30 minutes and $30 \mathrm{~mA}$ for 1 hour in the running buffer that was prepared by dissolving $6.0 \mathrm{~g}$ Tris-base, $28.8 \mathrm{~g}$ glycine, and $1.0 \mathrm{~g}$ SDS in distilled water and then adjusting the volume up to one litter. The proteins in the gel were stained with $\mathrm{CBB}$ and destained with $10 \%$ acetic acid solution.

\subsection{Statistical analysis}

The mean total protein content and phosphorus content were calculated using Statgraphic Centuri- on XV. Comparison of treatment means was performed by one-way analysis of variance (ANOVA), followed by LSD'multiple range test of Statgraphic Centurion $\mathrm{XV}$, and $\mathrm{p}<0.05$ was significantly different.

\section{RESULTS AND DISCUSSION}

\subsection{The effects of temperature on the purity of phosvitin}

Among the purification methods, thermal precipitation is relatively simple and an environmentally friendly technique to extract and purify proteins (Jung et al., 2013). Proteins in yolk granules have different thermal stabilities (Anton et al., 2007). Phosvitin and $\beta$-HDL are stable with temperature up to $82^{\circ} \mathrm{C}$, while LDL and $\alpha$-HDL are denatured at $72^{\circ} \mathrm{C}$ and $76^{\circ} \mathrm{C}$, respectively. Furthermore, proteins denatured by thermal treatment can be removed by centrifugation (Burgess, 2009). Therefore, phosvitin prepared by the method of Lee et al. (2014) was heat-treated at different temperatures $\left(30^{\circ} \mathrm{C}, 70^{\circ} \mathrm{C}, 80^{\circ} \mathrm{C}, 90^{\circ} \mathrm{C}\right.$, and $\left.100^{\circ} \mathrm{C}\right)$ in a water bath for $30 \mathrm{~min}$ to find out the optimal temperature for impurities removal from phosvitin extract (Table 1).

Table 1. The temperature effect on purification of phosvitin

\begin{tabular}{lrrr}
\hline $\begin{array}{l}\text { Temperature } \\
\left({ }^{\circ} \mathbf{C}\right)\end{array}$ & $\begin{array}{r}\text { Total protein content } \\
(\mathbf{m g})\end{array}$ & $\begin{array}{r}\text { Phosphorus content } \\
(\mathbf{m g})\end{array}$ & $\begin{array}{r}\text { Phosphorus recovery } \\
(\%)\end{array}$ \\
\hline 30 & $684.45 \pm 11.03^{\mathrm{a}}$ & $58.14 \pm 0.93^{\mathrm{a}}$ & $32.40 \pm 0.53^{\mathrm{a}}$ \\
70 & $506.10 \pm 13.77^{\mathrm{b}}$ & $57.10 \pm 0.26^{\mathrm{a}}$ & $31.80 \pm 0.17^{\mathrm{a}}$ \\
80 & $457.70 \pm 30.89^{\mathrm{c}}$ & $55.61 \pm 0.77^{\mathrm{b}}$ & $30.90 \pm 0.40^{\mathrm{b}}$ \\
90 & $418.21 \pm 3.82^{\mathrm{d}}$ & $54.87 \pm 0.68^{\mathrm{b}}$ & $30.60 \pm 0.36^{\mathrm{b}}$ \\
100 & $386.16 \pm 18.32^{\mathrm{d}}$ & $9.85 \pm 0.20^{\mathrm{c}}$ & $5.50 \pm 0.10^{\mathrm{c}}$ \\
\hline $\mathrm{CV}(\%)$ & 3.66 & 1.37 & 1.33 \\
\hline
\end{tabular}

*Note: Means in the same column that share a letter are not significantly different at $P<0.05$.

It was evident from Table 1 that the total protein content, phosphorus content, and phosphorus recovery rate decreased when the temperature increased. The total protein content was highest at $30^{\circ} \mathrm{C}$ treatment $(684.45 \mathrm{mg})$ and lowest at $100^{\circ} \mathrm{C}$ treatment $(386.16 \mathrm{mg})$. The phosphorus content and phosphorus recovery rate were highest at $30^{\circ} \mathrm{C}$ $(58.14 \mathrm{mg})$, this value did not significantly differ from that at $70^{\circ} \mathrm{C}(57.10 \mathrm{mg})$. At $100^{\circ} \mathrm{C}$ the phosphorus content and phosphorus recovery rate were lowest, $9.85 \mathrm{mg}$ and $5.50 \%$, respectively. This result was due to the denaturation and precipitation of all other granular proteins in the extracted phosvitin at high temperatures. The present work did not agree with the results of Jung et al. (2013); the total protein content, phosphorus content, and phosphorus recovery rate were not highest at $90^{\circ} \mathrm{C}$. The controversy in the protein content and phosvitin content might be due to the difference in the method of phosvitin separation and purification. 


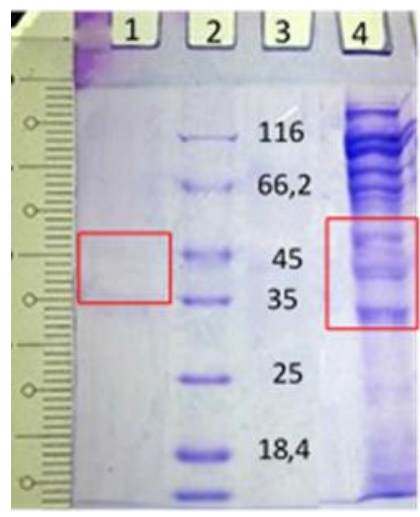

A

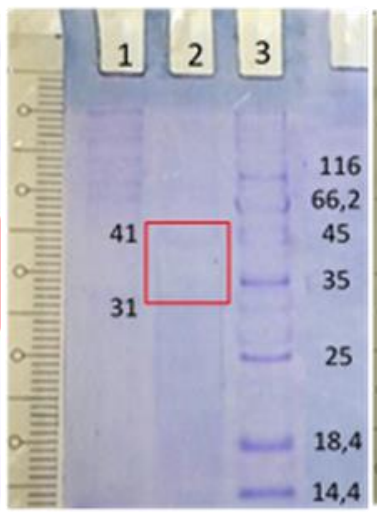

B

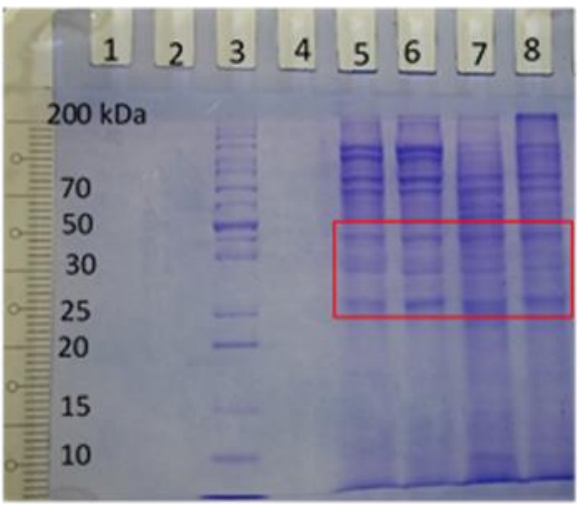

C

Fig. 1. Native polyacrylamide gel electrophoresis results

*Note:

A. Lane 1: Phosvitin standard (1 $\mu \mathrm{g})$; Lane 2: Molecular marker (116 kDa) (5 $\mu \mathrm{L})$; Lane 3: Empty, Lane 4: $30^{\circ} \mathrm{C}$

B. Lane 1: Empty; Lane 2: Phosvitin standard (1 $\mu \mathrm{g})$; Lane 3: Molecular marker (116 kDa) (5 $\mu \mathrm{L})$

C. Lane 1 and 2: Empty; Lane 3: Molecular marker (200 kDa) (5 $\mu \mathrm{L})$; Lane 4: Empty; Lane 5: 70 ${ }^{\circ} \mathrm{C}$; Lane 6: $80^{\circ} \mathrm{C}$; Lane 7: $90^{\circ} \mathrm{C}$; Lane $8: 100^{\circ} \mathrm{C}$

The SDS-PAGE results of phosvitin extract at different temperatures displayed that the phosvitin standard's molecular weight ranged from $31 \mathrm{kDa}$ to $41 \mathrm{kDa}$ (Fig. 1B). The final protein heat-treated at different temperatures had 3 main bands with a molecular weight of 29,37 , and $48 \mathrm{kDa}$ (Fig. 1A and $1 \mathrm{C}$ ). To compare with other researches (Abe et al., 1982; Anton et al., 2007), they confirmed that the extracted phosvitins were identical to standard phosvitin and 3 bands in the red square were phosvitin bands. In addition, when the temperature increased, some bands with molecular weight more

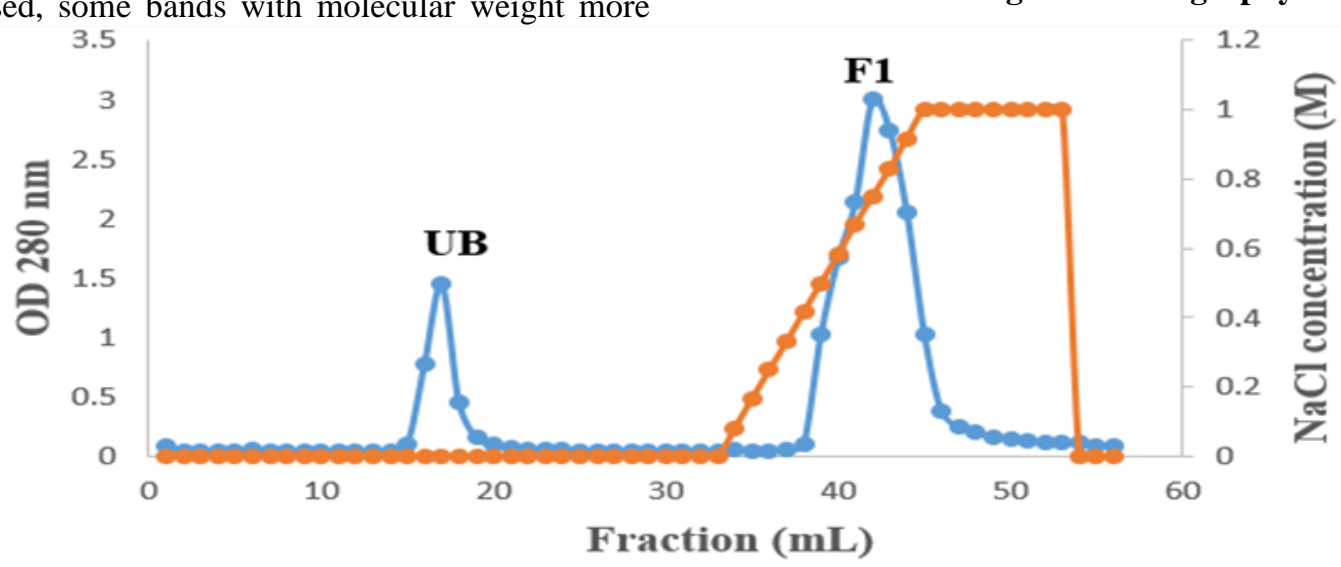

$\longrightarrow$ OD $280 \longrightarrow \mathrm{NaCl}$ concentration (M)

Fig. 2. Chromatographic profile of anion-exchange chromatography 
The phosvitin preparation obtained by the method of Lee et al. (2014) and heat-treated in a water bath at $30^{\circ} \mathrm{C}$ for 30 min was fractionated by AEC using UNO-Sphere $\mathrm{Q}$ column at the buffer solution of $\mathrm{pH}$ 8.0. The elution profile showed two peaks, the first one corresponding to the UB fraction and the larger one corresponding to fraction $1\left(\mathrm{~F}_{1}\right) . \mathrm{F}_{1}$ was eluted at $0.33 \mathrm{M} \mathrm{NaCl}$. This result was in line with studies of Castellani et al. (2003) and Zhang et al. (2011), which reported that phosvitin was eluted at $0.3 \mathrm{M}$ and $0.35 \mathrm{M} \mathrm{NaCl}$ by AEC using DEAE column at the buffer of $\mathrm{pH} 7.5$, respectively.

Table 2. The results of anion-exchange chromatography

\begin{tabular}{lrrrr}
\hline Fraction & $\begin{array}{r}\text { Total protein content } \\
(\mathbf{m g})\end{array}$ & $\begin{array}{r}\text { Phosvitin content } \\
(\mathbf{m g})\end{array}$ & $\begin{array}{r}\text { Phosvitin recovery } \\
(\boldsymbol{\%})\end{array}$ & $\begin{array}{r}\text { Phosvitin/protein } \\
\text { ratio (\%) }\end{array}$ \\
\hline Crude & $62.53 \pm 1.68$ & $39.50 \pm 0.11$ & 100.00 & 63.19 \\
UB & $1.28 \pm 0.04$ & $0.00 \pm 0.00$ & 0.00 & 0.00 \\
F $_{1}(\mathrm{AEC})$ & $38.53 \pm 0.58$ & $28.73 \pm 0.32$ & 72.73 & 74.56 \\
\hline
\end{tabular}

*Note: UB: unbound protein; $F_{1}$ : fraction 1; AEC: anion-exchange chromatography

Table 2 showed that the total protein content of $F_{1}$ was $38.53 \mathrm{mg}$ and the phosvitin content was 28.73 $\mathrm{mg}$ while UB fraction had a total protein content of $1.28 \mathrm{mg}$ and contained no phosvitin. This result indicated that most proteins in the isolated phosvitins obtained from $30^{\circ} \mathrm{C}$-treatment were bound to the resin in the chromatographic column. The fifth column in Table 2 also illustrated that the phosvitin/protein ratio increased from $63.19 \%$ in crude phosvitin extract to $74.56 \%$ in $\mathrm{F}_{1}$, meaning that only $11 \%$ of impurities were removed by AEC, therefore, the purity of phosvitin was not highly increased. Castellani et al. (2003) had reported that the eluted protein from AEC at $\mathrm{pH} 7.5$ contained

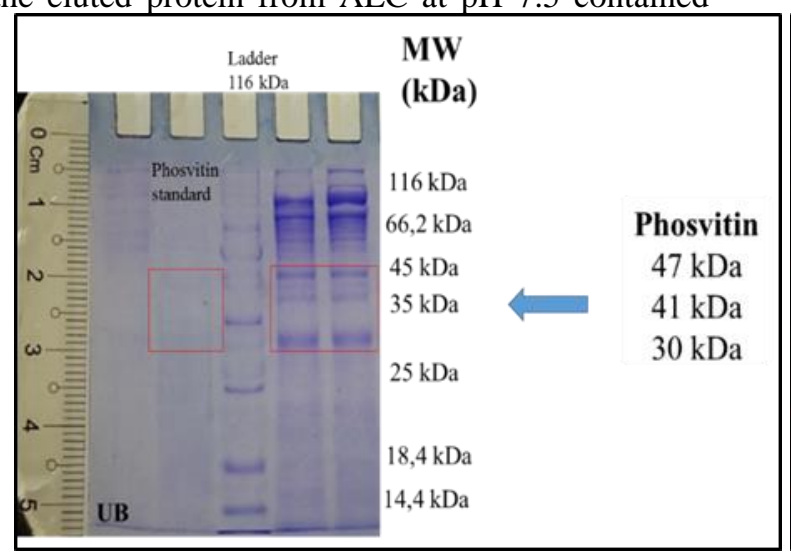

A high levels of impurities such as HDL and LDL contamination. $\mathrm{F}_{1}$ had the phosvitin recovery rate of $72.73 \%$ (calculated from crude phosvitin solution). This recovery rate was higher than that from Lei and Wu's (2012) research (35.4\%). It had reported that granules were directly loaded to the AEC column, so the high amount of lipid content had contaminated the column (Lei \& Wu, 2012). The presence of phosvitin in $\mathrm{F}_{1}$ was characterized using polyacrylamide-gel electrophoresis. Two similar gels were performed, one was stained with CBB (Fig. 3A), and the other with silver stain (Fig. 3B).

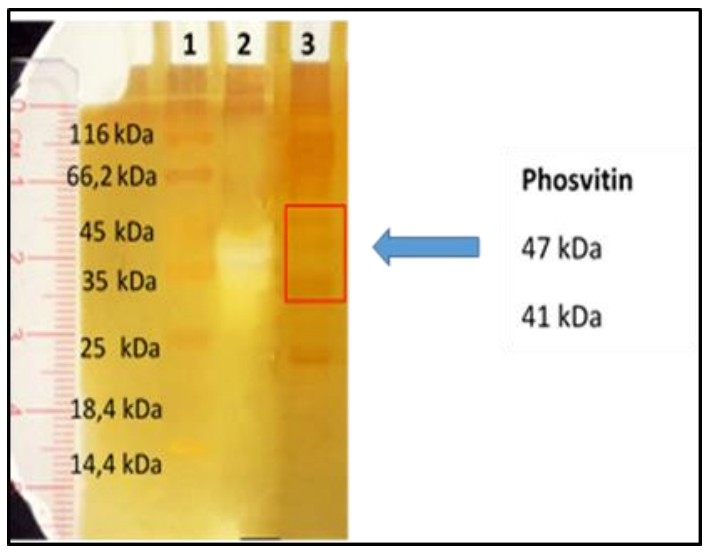

B

Fig. 3. Polyacrylamide electrophoresis of the fractions from anion-exchange chromatography in the normal form (A) and silver staining form (B)

*Note:

A: Lane 1: UB; Lane 2: Phosvitin standard (1 $\mu \mathrm{g})$; Lane 3: Molecular marker (116 kDa) (5 $\mu L)$; Lane 4 and 5: F1 (AEC) $(6 \mu g)$

B: Lane 1: Molecular marker (116 kDa) (5 $\mu \mathrm{L})$; Lane 2: Phosvitin standard (1 $\mu \mathrm{g})$; Lane 3: F1 (AEC) (6 $\mu \mathrm{g})$

From electrophoretic results, $\mathrm{F}_{1}$ obtained from the $\mathrm{AEC}$ at $\mathrm{pH} 8$ using UNO-Sphere Q resin had 3 major bands with molecular weights ranging from
30 to $47 \mathrm{kDa}$ and several bands spread in the slower moving region. However, the intensity of contaminated bands in the slower moving region was 
reduced in comparison to that in the crude sample. In contrast, UB fraction included many bands with no bands at the position of phosvitin standard. The electrophoretic results supported the results from Table 2 and agreed with the result of Castellani et al. (2003), which proved that $F_{1}$ obtained from AEC using DEAE-Cellulose at $\mathrm{pH} 7.5$ contained high levels of contamination such as HDL and LDL. This might be because at this $\mathrm{pH}$ most proteins in the crude phosvitin extract were negatively charged and bound tightly to the resins. Therefore, further purification (gel filtration) was carried out

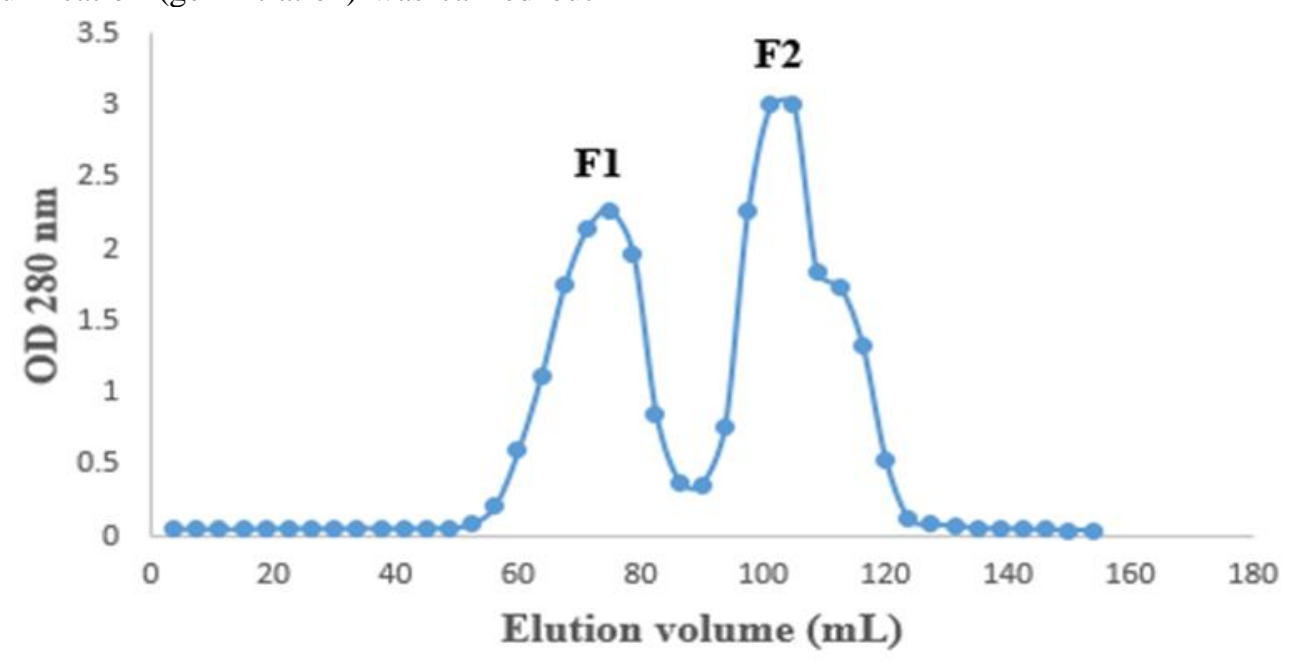

Fig. 4. Chromatographic profile of gel filtration chromatography

Table 3. The results from gel-filtration chromatography compared with anion-exchange chromatography

\begin{tabular}{lrrrr}
\hline Fraction & $\begin{array}{r}\text { Total protein content } \\
(\mathbf{m g})\end{array}$ & $\begin{array}{r}\text { Phosvitin content } \\
(\mathbf{m g})\end{array}$ & $\begin{array}{r}\text { Phosvitin recovery } \\
(\boldsymbol{\%})\end{array}$ & $\begin{array}{r}\text { Phosvitin/protein } \\
\text { ratio (\%) }\end{array}$ \\
\hline Crude & $62.53 \pm 1.68$ & $39.50 \pm 0.11$ & 100.00 & 63.19 \\
$\mathrm{~F}_{1}$ (AEC) & $38.53 \pm 0.58$ & $28.73 \pm 0.32$ & 72.73 & 74.56 \\
$\mathrm{~F}_{1}$ (GFC) & $5.78 \pm 0.53$ & $4.73 \pm 0.74$ & 12.00 & 81.93 \\
$\mathrm{~F}_{2}$ (GFC) & $12.73 \pm 0.87$ & $2.1 \pm 0.28$ & 5.40 & 16.89 \\
\hline
\end{tabular}

*Note: $F_{1}$ : fraction 1; $F_{2}$ : fraction 2; AEC: anion-exchange chromatography; GFC: gel-filtration chromatography

Table 3 showed that $\mathrm{F}_{1}(\mathrm{GFC})$ had a total protein content $(5.78 \mathrm{mg})$ lower than in $\mathrm{F}_{2}(12.73 \mathrm{mg})$. However, the phosvitin content in $\mathrm{F}_{1}$ (GFC) (4.73 $\mathrm{mg}$ ) was higher than that in $\mathrm{F}_{2}(2.1 \mathrm{mg})$. This might be speculated that $\mathrm{F}_{1}$ (GFC) contained mostly of $\beta$ phosvitin, which possesses a much higher phosphorus content than $\alpha$-phosvitin (Abe et al., 1982). Furthermore, the phosvitin content was calculated based on the phosphorus content, thus the phosvitin recovery rate of $F_{1}(\mathrm{GFC})(12 \%)$ higher than that of $\mathrm{F}_{2}(5.4 \%)$. Interestingly, the phosvitin/protein ratio to improve the purity of phosvitin and get highly purified phosvitin.

\subsection{Gel-filtration chromatography}

$\mathrm{F}_{1}$ from $\mathrm{AEC}$ at $\mathrm{pH} 8$ was fractionated into two peaks by gel filtration using Sephadex G-75 column named as $F_{1}$ (GFC) and $F_{2}$ (GFC). This result shared some similarities with previous results (Abe et al., 1982; Tsutsui \& Obara, 1982). In accordance with Abe et al. (1982), phosvitin was fractionated into two fractions on a Sephadex G-200 column.

\section{OD 280}

in $\mathrm{F}_{1}$ (GFC) reached $81.93 \%$, which was higher than that of $\mathrm{F}_{1}$ (AEC) at $\mathrm{pH} 8(74.56 \%)$. This indicated that the purity of the isolated phosvitin was increased after gel filtration.

Electrophoresis results demonstrated that $\mathrm{F}_{1}$ (GFC) had one band at a position around $45 \mathrm{kDa}$ and some minor bands in the slower region (Fig. 5B) while $F_{2}$ included three major bands located in the region ranging from 30 to $47 \mathrm{kDa}$ and some bands with molecular weight more than $66.2 \mathrm{kDa}$. In ac- 
cordance with findings of Anton et al. (2007), $\alpha$ phosvitin are composed of 3 or 4 small subunits with a molecular weight ranging from 30 to $45 \mathrm{kDa}$ while $\beta$-phosvitin contains 4 or 5 subunits with molecular weight mainly of $45 \mathrm{kDa}$. Therefore, it was confirmed that $F_{1}$ (GFC) was composed mainly of $\beta$-phosvitin, $F_{2}$ was abundant with $\alpha$ phosvitin. This result was in line with theory, $\beta$ phosvitin was more soluble than $\alpha$-phosvitin in the presence of $\mathrm{Ca}$ despite its higher phosphorus content (Abe et al., 1982), besides, $\beta$-phosvitin was resulted in a short elution time and eluted before $\alpha$ phosvitin because $\beta$-phosvitin had a higher molecu-

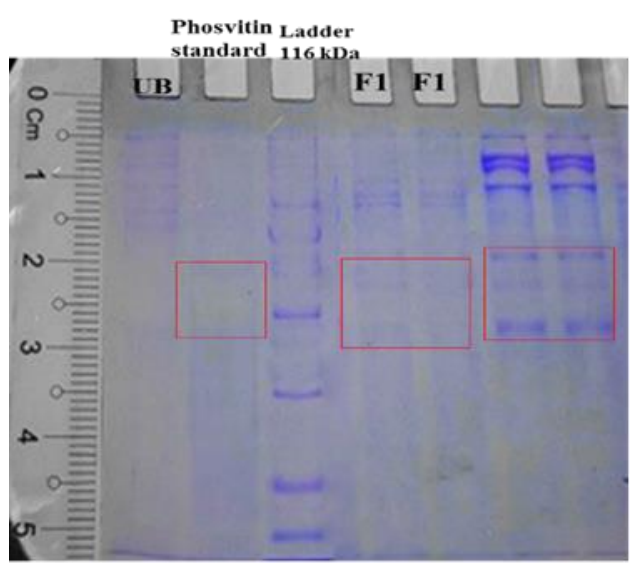

$\mathbf{A}$ lar weight than $\alpha$-phosvitin. As can be seen from the electrophoresis results in Fig. 5 and protein content in Table 3 , phosvitin obtained from $F_{1}$ (AEC) at $\mathrm{pH} 8$ was dominant with $\alpha$-phosvitin. The rate of $\alpha$-phosvitin and $\beta$-phosvitin in the extracted phosvitin rely on the kinds of chicken eggs and the method used to separate and purify phosvitin. Ultimately, phosvitin extracted from chicken eggs was fractioned into 2 fractions known as $F_{1}$ and $F_{2}$ by gel filtration using Sephadex G-75 column and the purity of phosvitin was improved after gel filtration.

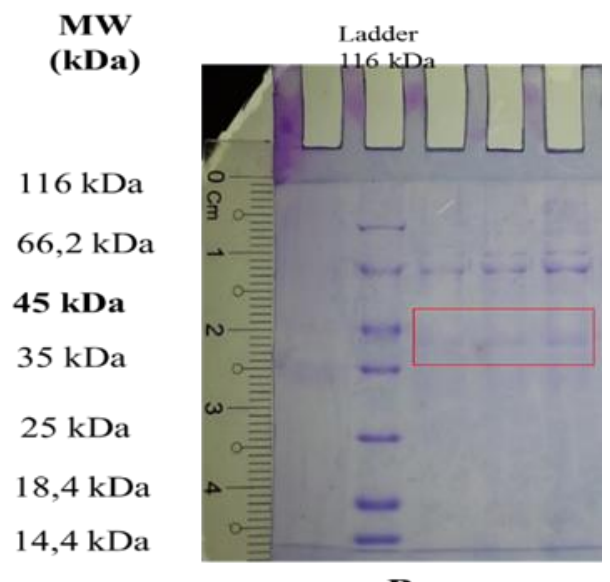

B

Fig. 5. Native polyacryamide electrophoresis of the fractions from gel filtration chromatography *Note:

A: Lane 1: UB (5 $\mu \mathrm{g})$; Lane 2: Phosvitin standard (1 $\mu \mathrm{g})$; Lane 3: Molecular marker (116 kDa) (5 $\mu \mathrm{L})$; Lane 4 and 5: $F_{1}(G F C)(1 \mu \mathrm{g}) ;$ Lane 6 and $7: F_{2}(G F C)(2 \mu \mathrm{g})$

B: Lane 1: Empty; Lane 2: Molecular marker (116 kDa) (5 $\mu \mathrm{L})$; Lane 3, 4 and 5: $F_{1}(G F C)(1 \mu g)$

\section{CONCLUSIONS}

In summary, the crude extract heat-treated at $30^{\circ} \mathrm{C}$ for 30 minutes gave the highest phosvitin and phosphorus contents, and phosphorus recovery yield. A consecutive procedure of anion-exchange and gel-filtration chromatography separated phosvitin into two sub-fractions, which were $F_{1}$ (GFC) with a high amount of $\beta$-phosvitin and $F_{2}$ (GFC) dominant with $\alpha$-phosvitin.

The high phosphorus content of phosvitin makes it an ideal protein to be used in many fields of human life. Although the phosvitin recovery rate from yolk granules in this study was not higher than $80 \%$, this method was relatively straightforward to manipulate, economical, ecologically friendly, and feasible for large-scale production. Taken together, this study provides a basis for future works on phosvitin's biological properties or antioxidant, antimicrobial, and metal chelating abilities.

\section{REFERENCES}

Abe, Y., Itoh, T., \& Adachi, S. (1982). Fractionation and characterization of hen's egg yolk phosvitin. Journal of Food Science, 47(6), 1903-1907.

Anton, M., Castellani, O., \& Guérin-Dubiard, C. (2007). Phosvitin: Bioactive Egg Compounds. Springer Press. Europe, pp. 17-24.

Bertrand, C. P. T. (2012). Development of antioxidant peptide fractions from egg yolk protein using enzymatic hydrolysis and ultrafiltration membranes (Publication No. 1032913130) [doctoral dissertation, Laval University]. https://www.baclac.gc.ca/eng/services/theses/Pages/item.aspx ?idNum ber $=1032913130$ 
Bradford, M. M. (1976). A rapid and sensitive method for the quantitation of Mirogram quantities of protein utilizing the principle of protein - dye binding. Analytical Biochemistry, 72(1-2), 248-254.

Burgess, R. R. (2009). Protein precipitation techniques. In: Methods in Enzymology: Guide to protein purificaion. Academic Press. USA, pp. 331-342.

Burley, R. W., \& Cook, W. H. (1961). Isolation and composition of avian egg yolk granules and their constituents $\alpha$ - and $\beta$-lipovitellins. Canadian Journal of Biochemistry and Physiology, 39(8), 1295-1307.

Castellani, O., Martinet, V., David-Briand, E., GuerinDubiard, C., \& Anton, M. (2003). Egg yolk phosvitin: preparation of metal-free purified protein by fast protein liquid chromatography using aqueous solvents. Journal of Chromatography B, 791(1-2), 273-284.

Causeret, D., Matringe, E., \& Lorient, D. (1991). Ionic strength and $\mathrm{pH}$ effects on composion and microstructure of yolk granules. Journal of Food Science, 56(6), 1532-1536.

Ishikawa, S., Yano, Y., Arihara, K., \& Itoh, M. (2004). Egg yolk phosvitin inhibits hydroxyl radical formation from the Fenton reaction. Bioscience, Biotechnology, and Biochemistry, 68(6), 1324-1331.

Jung, S., Nam, K. C., Ahn, D. U., Kim, H. J., \& Jo, C. (2013). Effect of phosvitin on lipid and protein oxidation in ground beef treated with high hydrostatic pressure. Meat Science, 95(1), 8-13.

Khan, S. M. A., Nakamura, S., Ogawa, M., Akita, E., Azakami, H., \& Kato, A. (2000). Bactericidal action of egg yolk phosvitin against Escherichia coli under thermal stress. Journal of Agricultural and Food Chemistry, 48(5), 1503-1506.

Ko, K. Y., Nam, K., Jo, C., Lee, E. J., \& Ahn, D. U. (2011). A simple and efficient method for preparing partially purified phosvitin from egg yolk using ethanol and salts. Poultry Science, 90(5), 1096-1104.

Lee, H. Y., Abeyrathne, E. D. N. S, Inwook, C., Suh, J. W., \& Ahn, D. U. (2014). Sequential separation of immunoglobulin Y and phosvitin from chicken egg yolk without using organic solvents. Poultry Science, 93(10), 2668-2677.

Lei, B., \& Wu, J. (2012). Purification of egg yolk phosvitin by anion exchange chromatography. Journal of Chromatography A, 1223, 41-46.

Mecham, D. K., \& Olcott, H. S. (1949). Phosvitin, the principal phosphoprotein of egg yolk. Journal of American Chemistry Society, 71, 3670-3679.

Pulliainen, T. K., \& Wallin, H. C. (1994). Determination of total phosphorus in foods by colorimetric measurement of phosphorus as molybdenum blue after dry-ashing: NMKL interlaboratory study. Journal of AOAC International, 77, 1557.

Tsutsui, T., \& Obara, T. (1982). Hydrophobic components in delipidated granule of egg-yolk. Agricultural and Biological Chemistry, 46(10), 2587-2589.

Zhang, X., Ning, Q., Feng, G., \& Meihu, M. (2011). Simply and effectively preparing high-purity phosvitin using polyethylene glycol and anion-exchange chromatography. Journal of Separation Science, 34(22), 3295-3301. 